\title{
Hamsa
}

Journal of Judaic and Islamic Studies

$4 \mid 2018$

Varia

\section{Why Ibn Ḥazm became a Zāhirī: Charisma, Law and the Court}

\section{Maribel Fierro}

\section{(2) OpenEdition \\ 1 Journals}

\section{Electronic version}

URL: https://journals.openedition.org/hamsa/486

DOI: 10.4000/hamsa.486

ISSN: 2183-2633

\section{Publisher}

CIDEHUS - Centro Interdisciplinar de História Culturas e Sociedades da Universidade de Évora

\section{Electronic reference}

Maribel Fierro, "Why Ibn Hazm became a Zāhirī: Charisma, Law and the Court", Hamsa [Online], 4 I 2018, Online since 31 March 2018, connection on 13 May 2021. URL: http://journals.openedition.org/ hamsa/486 ; DOl: https://doi.org/10.4000/hamsa.486

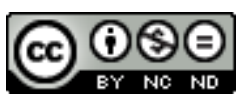

Hamsa est mise à disposition selon les termes de la Licence Creative Commons Attribution - Pas d'Utilisation Commerciale - Pas de Modification 4.0 International. 


\title{
Why Ibn Ḥazm became a Ẓāhirī: Charisma, Law and the Court*
}

\author{
Maribel Fierro \\ Instituto de Lenguas y Culturas del Mediterráneo (CCHS-CSIC) \\ maribel.fierro@cchs.csic.es
}

\begin{abstract}
Resumo:
O grande polígrafo cordovês Hazm (m. 456/1064) escolheu, como escola jurídica a seguir, a escola literalista ou zahirita em vez da malikita, a predominante em Al Andalus e a que tinha sido apoiada pelos omíadas de Córdova. A partir dos dados subministrados pela sua biografia pessoal e da sua trajetória política, assim como da análise de algumas das suas propostas doutrinais, conclui-se que a sua escolha se explica por uma visão de como queria que fosse a sociedade que o rodeava. Trata-se de uma conceção determinada pela sua formação no ambiente e cultura da corte omíada-amirida e pelo objetivo de evitar que os alfaquís tivessem, em exclusivo, o controlo do campo jurídico.
\end{abstract}

Palavras-chave: Ibn Hazm, Escola zahirida, Escola malikita, Omíadas, Amiridaes, Cultura cortesã, Direito Islâmico.

\section{Resumen:}

El gran polígrafo cordobés Ibn Hazm (m. 456/1064) escogió como escuela jurídica a la que seguir la escuela literalista o Z̦āhirí en vez de la mālikí que era la predominante en al-Andalus y que había sido apoyada por los omeyas de Córdoba. A partir de los datos suministrados por su biografía personal y su trayectoria política así como del análisis de algunas de sus propuestas doctrinales se concluye que su elección se explica por su visión de cómo quería que fuera la sociedad que le rodeaba. Se trata de una visión determinada por su formación en el ambiente y en la cultura de la corte omeya-amirí y por el objetivo de evitar que los alfaquíes tuvieran en exclusiva el control del campo jurídico.

Palabras clave: Ibn Hazm, Escuela zāhirī, Escuela mālikí, Omeyas, 'Āmiríes, Cultura cortesana, Derecho islámico.

\begin{abstract}
:
The great Cordoban polygraph Ibn Hazm (d. 456/1064) chose as the legal school to follow the literalist or Z̄āhirī, instead of the Mālikī legal school that was the predominant in al-Andalus and that had been supported by the Cordoban Umayyads. On the basis of the information provided by his personal biography and his political trajectory as well as of the analysis of some of his doctrinal conclusions, I conclude that his election is explained by his vision of how he wanted society to be. It was a vision determined by his formation in the Umayyad-'Āmirid court context and culture, and by his rejection that jurists would have exclusive control of the legal sphere.
\end{abstract}

Key Words: Ibn Hazm, Zāhirī school, Mālikī school, Umayyads, 'Āmirids, Court culture, Islamic Law. 


\section{Ibn Ḥazm: Political Problems, Legal Solutions}

In the medieval Islamic West, in the $4^{\text {th }} / 10^{\text {th }}$ century, Andalusi society was characterized by having a strong, long-standing state and the support of a powerful network of specialists in religious learning, principally jurists. The collective memory engendered by these specialists provided continuity in religious knowledge ('ilm) beginning with the arrival of Islam in the Iberian Peninsula in the $2^{\text {nd }} / 8^{\text {th }}$ century up to their own time. This continuity was related to how they had managed the knowledge of the Revelation and the prophetic legacy as a means of assuring salvation in the afterlife, for both ruler and the ruled, by leading them along the straight path during this life ${ }^{1}$. A different kind of society or societies could be found throughout most of the far western Maghreb (present-day Morocco), where there was no similar network of religious scholars until the Almoravid period and especially during the Almohad period $\left(6^{\text {th }} / 12^{\text {th }}-7^{\text {th }} / 13^{\text {th }}\right.$ centuries) and where it was relatively common to find messianic or saintly figures who were charged with managing both the sacred sphere and conflicts among tribes. In some cases, these figures were able to provide the initial impetus for the creation of states ${ }^{2}$. In al-Andalus, however, these charismatic figures rarely succeeded in forming lasting political structures ${ }^{3}$. The reasons for their relative failure are many, among which we may mention the difficulty in recruiting an army in al-Andalus - a task that was facilitated in North Africa by the tribal context - as well as the existence of a deep anti-charismatic tendency among Andalusi religious scholars ${ }^{4}$. This tendency was strongest in the work of one of the most interesting and controversial thinkers in the history of the medieval Islamic West, Ibn Hazm of Córdoba (d. 456/1064), whose place within Sunni Islam has been the subject of debate because he followed the literalist or Zāairī school of thought.

\footnotetext{
* This article was written as part of the project "Practicing knowledge in Islamic societies and their neighbors" with funding from the Humboldt Foundation (Anneliese Maier Award 2014). An earlier version was read for a panel on Ideology and society in the Middle Ages that that took place on June 28, 2014, at the Universitat de Lleida, and at the Symposium New Perspectives on al-Andalus: Agents and Objects in the Field of Cultural Production, April 7, 2017, Real Colegio Complutense (Harvard). I wish to thank Christopher Melchert for his comments and Virginia Vázquez for her help.

${ }^{1}$ Maribel Fierro and Manuela Marín, "La islamización de las ciudades andalusíes a través de sus ulemas (ss. II/VIII-comienzos s. IV/X)", in Genèse de la ville islamique en al-Andalus et au Maghreb occidental, ed. Patrice Cressier and Mercedes García-Arenal, Madrid, Casa de Velázquez, 1998, p. 65-98; Maribel Fierro, "Why and how do religious scholars write about themselves? The case of the Islamic west in the fourth/tenth century", Mélanges de l'Université Saint-Joseph58 (2005), p. 403-423.

${ }^{2}$ Mercedes García-Arenal, Messianism and puritanical reform: Mahdis of the Muslim West, Leiden-Boston, Brill, 2006; Mehdi Ghouirgate, L'Ordre almohade (1120-1269): une nouvelle lecture anthropologique, Toulouse, Presses universitaires du Mirail, 2014.

${ }_{3}$ Maribel Fierro, "Doctrinas y movimientos de tipo mesiánico en al-Andalus", in Milenarismos y milenaristas en la Europa Medieval. IX Semana de Estudios Medievales (Nájera, del 3 al 7 de agosto de 1998), Logroño, Instituto de Estudios Riojanos, 1999, p. 159-175 (extended and updated version of "Mahdisme et eschatologie dans al-Andalus", in Mahdisme. Crise et changement dans I'histoire du Maroc. Actes de la table ronde organisée à Marrakech par la Faculté des Lettres et des Sciences Humaines de Rabat du 11 au 14 Février 1993, ed. Abdelmajid Kaddouri, Rabat, Publications de la Faculté des Lettres et des Sciences Humaines, 1994, p. 47-69).

${ }^{4}$ On these differences, see Maribel Fierro, "Entre el Magreb y al-Andalus: la autoridad política y religiosa en época almorávide", in Balaguer, 1105. Cruilla de civilitzacions. Reunió Científica. X Curs d'Estiu Comtat d'Urgell celebrat a Balaguer els dies 13, 14 i 15 de juliol de 2005 sota la direcció de Flocel Sabaté i Maribel Pedrol, ed. Flocel Sabaté,Lleida, Pagés, 2007, p. 99-120, citing Ernest Gellner (Muslim society, Cambridge, Cambridge University Press, 1981 and Saints of the Atlas, Chicago, Chicago University Press, 1969). On the tendency of Sunni Islam to exclude charisma, see Norman Calder, "The limits of Islamic orthodoxy", in Intellectual traditions in Islam, ed. Farhad Daftary, London, I.B. Tauris, 2000, p. 66-86, reproduced in Orthodoxy and heresy in Islam: Critical Concepts in Religious Studies, ed. Maribel Fierro, London-New York, Routledge, 2013. 4 vols.
} 
Ibn Hazm is best known as the author of a famous treatise on love and lovers, Tawq alhamāma ${ }^{5}$, as well as for having written a book that Miguel Asín Palacios analyzed under the title Historia crítica de las ideas religiosas, which contains a ferocious polemic not only against other religions - especially Judaism and Christianity - but also against Islamic sects that in the opinion of the author had strayed from the straight path, among them Shi'i Islam, the quintessentially charismatic variety of Islam ${ }^{6}$. Ibn Hazm's oeuvre is not limited to these two works, but also includes books on law, Qur'anic sciences, the Tradition of the Prophet, history, genealogy, ethics, philosophy, poetry, and much more, so that he is rightly referred to as a polymath?

Ibn Hazm was born into a family whose fortunes were closely tied to the Umayyad dynasty in Córdoba. Although his ancestors - whose ethnic background is unknown but which most probable was Hispanic - had converted to Islam after 711, when the Iberian Peninsula was conquered by the Muslims ${ }^{8}$, one of those ancestors claimed to be of Persian origin, meaning that the conversion to Islam and the patron-client relationship with the Umayyads would have extended back to the period before the conquest of al-Andalus. What was behind this genealogical claim was the right to affirm that the patron-client relationship of the Banū Hazm family with the Umayyads was more long-standing than that of those who had converted after the conquest in 711. It was thus a matter of precedence, which was intended to position the Banū Hazm family at the top of the hierarchy of other Umayyad clients who worked - like them - in the Cordoban administration ${ }^{9}$. Belonging to the group of these clients, the Umayyad mawāli, was not an inconsequential matter, as is clear from the hierarchized position that these mawāli occupied in caliphal ceremonies during the $4^{\text {th }} / 10^{\text {th }}$ century ${ }^{10}$.

Undoubtedly influenced by his background and the history of his immediate family, Ibn Hazm was an Umayyad legitimist; in other words, for him the Umayyads were the only legitimate rulers, and he fought in word and deed to preserve the Umayyads on the Cordoban throne. He was moreover a legitimist who was steadfast in his political ideology during the tumultuous times that led up to the abolition of the Umayyad caliphate of Córdobain the year 422/1031 by a group of prominent Cordobans ${ }^{11}$. This time of upheaval had begun with the proclamation of Hishām II as caliph of Córdoba in 366/976. He was a minor and therefore not qualified to rule according to mainstream Sunni legal doctrine, and this fact had permitted Ibn Abī 'Āmir, known as Almanzor, to become the de facto ruler. Almanzor was a Southern Arab who had worked his way up through

\footnotetext{
${ }^{5}$ This work is more of a best-seller today than it was in the past, given that there is only one extant manuscript of it. For the numerous editions, translations, and studies, see the bibliography included in $I b n$ Hazm of Cordoba. The Life and Works of a Controversial Thinker, ed. Camilla Adang, Maribel Fierro, and Sabine Schmidtke, Leiden, Brill, 2012.

${ }^{6}$ Miguel Asín Palacios, Abenházam de Córdoba y su Historia Crítica de las ideas religiosas, Madrid, Real Academia de la Historia, 1928-1932. 5 vols.

${ }^{7}$ An overview in Ibn Hazm of Cordoba...

${ }^{8}$ According to Josep Puig, "Ibn Hazm y el estoicismo representado por Séneca", Revista del Instituto Egipcio de Estudios Islámicos 27 (1995), p. 79-96, p. 83, his family was probably of Berber origin, although I do not know what this assertion is based on.

${ }^{9}$ On the debate about the genealogy of Ibn Hazm, see Maribel Fierro,"El conde Casio, los Banu Qasi y los linajes godos en al-Andalus", Studia Historica. Historia Medieval (Los mozárabes entre la Cristiandad y el Islam) 27 (2009), p. 181-189.

${ }^{10}$ Miquel Barceló, "El califa patente: el ceremonial omeya de Córdoba o la escenificación del poder", in Estructuras y formas del poder en la historia, ed. Reyna Pastor de Togneri et al., Salamanca, Universidad de Salamanca, 1991, p. 51-71; reproduced in Madīnat al-Zahrā: El salón de 'Abd al-Rahman III, ed. Antonio Vallejo Triano, Córdoba, Junta de Andalucia, 1995, p. 155-175 and in El sol que salió por Occidente. Estudios sobre el estado omeya en al-Andalus, Jaén, Universidad de Jaén, 1997, p. 137-162. English trans. "The Manifest Caliph: Umayyad Ceremony in Córdoba, or the Staging of power", in The Formation of al-Andalus. Part 1: History and Society, ed. Manuela Marín, Ashgate, Variorum, 1998 (The Formation of the Classical Islamic World, vol. 46), p. 425-456.

${ }^{11}$ On the context of this abolition, see David Wasserstein, The caliphate in the West. An Islamic Political Institution in the Iberian Peninsula, Oxford, Clarendon Press, 1993.
} 
the Umayyad administration, eventually becoming chamberlain of the young caliph. To bolster his power, he relied on the support of the șaqăliba (slaves of mostly Slavic origin), who were linked to him through patron-client relationships and whom he employed in various capacities in the administration and palace, whereas for the military he relied mostly on Berber troops imported from North Africa ${ }^{12}$. This gave rise to the 'Ämirid system of government, in which the figure of the caliph was left in place, though he was stripped of any de facto power. Almanzor and his son al-Muzaffar were able to govern without completely alienating the support of the Umayyad legitimists until the death of al-Muzaffar in 399/1008, when his half-brother 'Abd alRaḥmān Sanchuelo had himself proclaimed as the successor of Hishām II. Thus began a period of civil war in which the Berber troops that had arrived from North Africa in the preceding decades played a major part. During a period of more than twenty years, numerous ephemeral Umayyad caliphs succeeded one another on the Cordoban throne, as well as caliphs that were members of another dynasty, the Idrisids-Hammudids, who were direct descendants of the Prophet Muhammad and who had come from the other side of the Strait of Gibraltar and were supported predominantly by Berbers ${ }^{13}$.

In the meantime, the Iberian Peninsula was being broken up into various independent realms, giving rise to the Taifa kingdoms. Some of these territories were theoretically loyal to the Umayyads, while others opted to proclaim obedience to an imām 'abd allāh amìr al-mu'mininn, a formula in which "'abd allāh" could be understood as a reference to the Abbasid caliph but also simply as the vague caliphal title "servant of God"; in other words, the formula basically acknowledged caliphal authority without specifying which authority was being referred to ${ }^{14}$. Throughout this entire process, Ibn Hazm remained loyal to the Umayyads. Once there was no longer any hope of seeing them returned to the throne, Ibn Hazm devoted himself to composing an extensive legal work based on Zāainī legal doctrine - of which he had become an advocate during his years of political struggle - where he strove to present an alternative to the legal school that had predominated in al-Andalus up to that time ${ }^{15}$.

The latter school, called Mālikism, had been supported by the Cordoban Umayyad dynasty, whose rulers had designated it as a sort of official doctrine because it was associated with the city of Medina, in other words, with the period in the life of the Prophet when he was not only a prophet but also a head of state. This association of the Māliki school with Medina allowed the Umayyads in Córdoba to emphasize their independence from the Abbasid caliphate in Baghdad, which had inclined to the other legal school then in existence, the Hanafi school, which was associated especially with Iraq. But above all, choosing Mālikism allowed the Cordoban Umayyads to present themselves as the heirs of the prophecy, thus rivaling the Fatimids, who were Ismā'îi Shi'i Muslims and whose founding of a caliphate in North African was a blow to Umayyad legitimacy, since the Fatimid imam-caliph was a direct descendant of the Prophet Muhammad and claimed moreover to possess the Prophet's charisma. The Māliki school and Umayyad government thus went hand in hand in al-Andalus, the former helping to bolster the religious legitimacy of the latter. ${ }^{16}$

\footnotetext{
12 Xavier Ballestin, Al-Mansur y la dawla 'amiriya: una dinámica de poder y legitimidad en el occidente musulmán medieval, Barcelona, Universitat de Barcelona, 2004.

${ }^{13}$ Peter C. Scales, The fall of the caliphate of Córdoba. Berbers and Andalusis in conflict, Leiden, Brill, 1994; María Dolores Rosado Llamas, La dinastía hammudí y el califato en el siglo XI, Málaga, Universidad de Málaga, 2008.

${ }^{14}$ About this see Wasserstein's book cited in note 11 and François Clément, Pouvoir et légitimité en Espagne musulmane à l'époque des Taifas (Ve/XIe siècle). L'imam fictif, Paris, l'Harmattan, 1997, p. 245.

${ }^{15}$ Camilla Adang, "From Mālikism to Shāfi'ism to Zāhirism: the 'conversions' of Ibn Ḥazm", in Conversions islamiques. Identités religieuses en Islam méditerranéen, ed. Mercedes García-Arenal, Paris, Maisonneuve et Larose, 2001, p. 73-87.

${ }^{16}$ Maribel Fierro, "La política religiosa de 'Abd al-Raḥmān III", Al-Qanțara 25 (2004), p. 119-156 and "ProtoMālikīs, Mālikīs and reformed Mālikīs", in The Islamic School of Law: Evolution, Devolution, and Progress,
} 
Why did Ibn Hazm's steadfast support for Umayyad legitimacy - bordering on fanaticism according to the chronicler Ibn Ḥayyān ${ }^{17}$ - not deter him from abandoning the Mālikĩ cause? Why did he not consider this rejection to be a betrayal of the Umayyad cause? And why did he choose the literalist or Zāhirī tradition, a marginal doctrine within Sunni Islam?

To begin to answer these questions, we should recall that Ibn Hazm became interested in religious learning relatively late in his youth (he had been born in 394/994). According to his own account, in about 410/1019-1020, when he was in Córdoba attending the burial of a friend of his father's, he realized that he did not know the correct way to pray the funeral prayer. This inspired him to study law (figh), and after only three years of study with Ibn Daḥhūn, a Mālikī teacher, he was able to debate soundly on matters of religion ${ }^{18}$. He had thus come late to the study of Mālikism and perhaps because of that, it was not difficult for him to give it up, although it is not until ten years later that we can document his conversion to Zāhirism, a process that will deepen later on, during his stay in Denia.

Ibn Hazm had been educated at the Umayyad-'Āmirid court and seemed destined to follow a career path similar to that of his father (d. 402/1012), who had been vizier to Almanzor and his sons. In other words, Ibn Hazm seemed ordained to work at court, since he had been inculcated in its culture. This was a culture in which poetry, belletristic literature (adab), genealogy, and history were given precedence, while limited attention - only what was absolutely required - was paid to religious learning. Ibn Hazm excelled in these profane and humanist branches of learning that he was trained in during his youth. Later, his life and that of his family were greatly disrupted by the crisis in the caliphate, especially the death of Almanzor's son, al-Muz̧affar (m. 399/1008), the rise of his brother Sanchuelo, the dethroning of Hishām II, and the assumption of Muhammad al-Mahdi in 399/April 26, 1009. After the assassination of alMahdi and Hishām II's return to the throne, Ibn Hazm's father was persecuted by the caliph's new favorite, the Slav general Wādih, who had him imprisoned and seized his property. His father died during a failed uprising against the Slav, when Ibn Hazm was eighteen years old. The following year Córdoba was sacked by Berber troops under Sulaymān al-Musta'in, and the Banū Hazm family was left homeless while the young Ibn Ḥazm was forced to flee Córdoba (404/1013). Bruna Soravia has reconstructed the nearly twenty years between his flight and the abolition of the Umayyad caliphate in 422/1031 and has shown that, during those years, Ibn Hazm moved in the circles of 'Ämirid clients - many of them former slaves or șaqāliba- who sought to reconstruct or recover the system put in place by Almanzor, forging and dissolving sundry alliances that could be disadvantageous to the faction to which they belonged ${ }^{19}$. To summarize the facts, Ibn Hazm made his way to Almería' but he was forced to flee in 407/1016, when the Slavic lord of the city - a member of the 'Āmirid mawāli who had transferred his loyalties to the Hammudid caliph - accused him of plotting on behalf of the Umayyads. After taking refuge in Hịșn al-Qașr with Ibn Hudhayl al-Tujībī, he later made his way to Valencia to join the followers of

ed. Peri Bearman, Rudolph Peters and Frank E. Vogel, Cambridge, Mass., Harvard University Press, 2006, p. 57-76.

${ }^{17}$ Abdel Majid Turki, "L'engagement politique et la théorie du califat d'Ibn Hazm (384/456-994/1063)", Bulletin d'études orientales30 (1978), p. 221-251, reprinted in idem, Théologiens et juristes de l'Espagne musulmane, aspects polémiques, Paris, Maisonneuve et Larose, 1982, p. 69-99.

${ }^{18}$ M. Asín Palacios, Abenházam..., vol. I, p. 106-107; Emilio García Gómez, "Introduction" in 'Alī ibn Ahmad Ibn Hazm, El collar de la paloma. Tratado sobre el amor y los amantes de Ibn Hazm de Córdoba, translated by Emilio García Gómez, with a prologue by José Ortega y Gasset, Madrid, Sociedad de Estudios y Publicaciones, 1952, reprinted Madrid, Alianza Editorial, 1997, p. 33, who is surprised that Ibn Hazm claims not to have known at such a late age how to say the prayer. On Ibn Hazm's teachers, see Muhammad alManūnī, "Shuyūkh Ibn Ḥazm fī maqrū'ātihi wa-marwiyyātihi", al-Manāhil 7 (1976), p. 241-261.

${ }^{19}$ Bruna Soravia, "A portrait of the 'ālim as a young man: the formative years of Ibn Hazm, 404/1013420/1029" in Ibn Hazm of Cordoba..., p. 25-50. What follows is based primarily on this illuminating study. I have also used Samir Kaddouri, "Dissimulation des opinions politiques sous contrôle: le cas d'Ibn Hazm à Séville", Al-Qanțara 35-1 (2014), p. 135-150. 
a great-grandson of 'Abd al-Rahmmān III who sought to recover the throne of his ancestors. With the title of al-Murtaḍa and with the backing of Khayrān, the ruler of Almería, and al-Mundhir, king of Zaragoza, the Umayyad claimant set out to take Córdoba, whose Hammudid caliph had just been assassinated. Al-Murtaḍā first waged battle against the Zirids in Granada, where Ibn Hazm was taken prisoner, and shortly thereafter al-Murtaḍa was killed in Guadix by hired assassins sent by Khayrān. In 409/February-March 1019, Ibn Ḥazm was in Córdoba (it was during this visit that he decided to undertake his study of religious learning). Around the year 412413/1022 we find him in Játiva. In 414/December 1023, the Cordobans elected 'Abd al-Rahmān al-Mustaz̧hir as caliph, and he summoned his friends Ibn Hazm and his cousin, as well as the famous poet and man of letters Ibn Shuhayd (d. 426/1035) ${ }^{20}$, whom he appointed viziers. But the new caliph was only on the throne for a month and a half and was executed on January 17 , 1024. Again Ibn Hazm had to flee Córdoba, though he returned to serve the last Umayyad caliph of the city, Hishām III al-Mu'tadd (420/1029-422/1031), who probably named him vizier. Hishām III had been living outside Córdoba, in the small kingdom of the Berber Banū Qāsim de Alpuente, where Ibn Hazm also took up residency. Al-Mu'tadd followed the practice of ruling through a favorite, in this case Hakam al-Qazzāz, a member of a rich and powerful merchant family. Together they attracted support from the 'Āmirid clients, a group made up of people whose social advancement had been concomitant with Almanzor's political ascent, as well as those Umayyad clients who stood to gain from the form of government established by Almanzor and therefore looked favorably on him. Ibn Hazm was part of this group not only as a matter of political conviction but also because of deep ties of friendship and a common culture. Al-Mu'tadd was able to hold on to power for two years before he was deposed (and al-Qazzāz was executed) by a faction that had emerged from among the 'Âmirid clients and decided that the system had outlived its usefulness and undertook to abolish the Umayyad caliphate ${ }^{21}$.

Al-Mu'tadd's ouster put an end to Ibn Hazm's political career. After once more abandoning his native city, he spent the last part of his life wandering here and there throughout al-Andalus. He applied himself to study and to writing his legal and religious work, through which he would articulate his vision of Islamic society, which - as we will see - had no place for any kind of charismatic leadership after the death of the Prophet ${ }^{22}$. In his view, the law understood according to the Zāhirī school reduced what was ordained and prohibited by Revelation to a minimum and, moreover, subjected Revelation to an interpretation that was carried out in a specific way, to which we will return below. In such a society, there was room for social, cultural, and religious practices that, as we will see in the last part of this study, seem to be in agreement with the interests and tastes of the courtly milieu in which Ibn Hazm had been brought up; at the same time, from a theological and doctrinal point of view, he sought to reduce as much as possible the anguish over death and destiny in the afterlife.

In the year 429/1038, Ibn Hazm was in Almería with Zuhayr, but after the latter's defeat by Bādīs of Granada he was imprisoned. He later offered his services to the rulers of Denia and resided in Majorca for a time, where he took part in a famous polemic with Māliki jurists ${ }^{23}$. He left Majorca, made his way to Denia, then again to Almería between 441/1049 and 445/1053,

\footnotetext{
${ }^{20}$ Jorge Lirola Delgado [except work no 6 by Ignacio Ferrando], "Ibn Šuhayd, Abū 'Āmir" in Biblioteca de alAndalus, vol. 5: De Ibn Sa'āda a Ibn Wuhayb, ed. Jorge Lirola Delgado, Almería, Fundación Ibn Tufayl de Estudios Árabes, 2007, p. 403-412, no 1193.

${ }^{21}$ We will later take a look at the possible economic motives behind al-Mu'tadd's overthrow and the decision to put an end to the caliphate.

${ }^{22}$ Although he did continue to insist on the need to remember and to exalt the charisma of the Prophet: Linda G. Jones, "Prophetic performances: reproducing the charisma of the prophet in medieval Islamic preaching", in Charisma and Religious Authority: Jewish, Christian, and Muslim Preaching, 1200-1500, ed. Katherine L. Jansen and Miri Rubin, Turnhout, Brepols, 2010, p. 19-48.

${ }^{23}$ Abdel Magid Turki, Polémiques entre Ibn Hazm et Bāğĩ sur les principes de la loi musulmane, essai sur le littéralisme zāahirite et la finalité mālikite, Algiers, Société Nationale d’Édition et de Diffusion, 1976.
} 
whence he relocated to Seville - where his books were burned by al-Mu'tadid (433/1042461/1069) - and finally took refuge in his homeland of Niebla, where he died in 456/1064.

Ibn Hazm was often at the heart of contemporary political life, especially during his early years, when he still dreamed of the restoration of the Umayyads and worked to make this dream a reality. As we have seen, his father had been one of the men whose rise in social status had been made possible by Almanzor, and Ibn Hazm moved among people with similar life experiences. His political vision for al-Andalus revolved around an Umayyad caliph surrounded and supported by the group to which he belonged, a group equipped with common political and cultural values, although differences of opinion, both major and minor, did develop. In the next section, I am going to focus on one of these values, the rejection of charisma, which is one of the fundamental components of Ibn Hazm's legal and political doctrine. In order to understand this rejection, we must understand what the political implications of charisma were for Ibn Hazm's world after the collapse of the Cordoban Umayyad caliphate. This was also the time when Mâliki judges and jurists acquired a protagonist role that sometimes led them to becoming rulers, a development that will be dealt with in the third section. In the final section, I will return to Ibn Hazm's family background, and to his deep attachment to the 'Āmirid-Umayyad court and its cultural and intellectual values to explain why Ibn Ḥazm abandoned Mālikism²4.

\section{The Emergence of Charisma in al-Andalus: The Religious, Political, and Military contexts}

Charisma is understood as that difficult-to-define quality that sets certain individuals apart - sometimes to the extent of their being attributed supernatural powers - such that they are taken as moral examples or possessors of spiritual, religious, or political leadership ${ }^{25}$. Ibn Hazm considered this charismatic authority to be absolutely confined to the prophets-including the ability to perform miracles or have access to the occult, which even among them was very rare - and naturally he believed that such abilities had come to an end with the death of Muhammad, the last of the prophets ${ }^{26}$. This was a fundamental point in the doctrinal and political struggle pitting the Umayyads against the Fatimids, whose imam-caliph claimed to have inherited the charisma of the Prophet (he had supernatural knowledge and could perform miracles). This charisma had helped the Fatimids gain the support of a Berber tribe, the Kutāma, who in turn had helped them establish their caliphate in North Africa, which was still in existence in Ibn Hazm's day, although its capital had been moved to Egypt. Even though the political and military threat posed by this caliphate was no longer as acute as it had been in the $4^{\text {th }} / 10^{\text {th }}$ century, the Fatimids continued to pose a doctrinal threat with their claim to truth and certainty by virtue of following an imam that was a direct delegate of God (khalīfat Allāh). In al-Andalus, the Hammudid caliphs also tried to give a charismatic spin to their genealogy.

For the Sunnis, such audacity implied that the Ismā'ilis tolerated too much proximity between their imām and the figure of the Prophet. For them, there would never be another prophet, and all those who appeared after the death of Muhammad were false prophets, like those who had arisen in the Islamic West from very early times after the Islamic conquest and

\footnotetext{
${ }^{24} \mathrm{Ibn}$ Hazm's life, works and times have been the object of many studies on which I am indebted as reflected in the notes. In this paper the main aim is not to propose or look for new evidence but to make better sense of that already known.

${ }^{25}$ The standard definition is found in Max Weber, Wirtschaft und Gesellschaft (Tübingen, J.C.B Mohr, 1922), in the chapter on "Charismatische Herrschaft". http://www.textlog.de/7415.html [Last accessed 13/12/2017]. The work has been translated into numerous languages.

${ }^{26} \mathrm{Ibn}$ Hazm held that even prophets- as human beings and not angels -were prone to error and thus to correction on the part of God: Camilla Adang, "Reading the Qur'ān with Ibn Hazm: The question of the sinlessness of the prophets", in Controverses sur les écritures canoniques de l'islam, ed. Daniel De Smet and Mohammad Ali Amir-Moezzi, Paris, Editions du Cerf, 2014, p. 269-296.
} 
who had mobilized certain tribes with their preaching. These figures provide a clear illustration of the process of acculturation of those tribes to the new Islamic religion. Some examples are the prophet of the Barghawāța, who possessed a Qur'an in the Berber language, whose followers were settled all along the Atlantic coast of present-day Morocco, and whose "state" lasted 400 years (persisting even in Ibn Hazm's day), as well as the prophets of the Ghumāra and of Lisbon, who were active in the time of 'Abd al-Rahmān III, bearers of a revelation that brought together ancestral customs formulated in a language akin to that of Islam ${ }^{27}$.

Ibn Hazm also utterly rejected the appeal of esotericism and felt no attraction whatsoever to Sufism or to saintly figures. He condemned the mystics in all religions, asserting that religion has no hidden secrets ${ }^{28}$. He was emphatically opposed to the possibility that there were men other than the prophets who could work miracles ${ }^{29}$. Not everyone thought like him: during Almanzor's time there were those in Córdoba who claimed that some human beings were capable of performing extraordinary feats that could alter the normal course of events and therefore manifested a special, direct contact with the divine, whereas others denied such a possibility. This polemic included a debate over whether women who were prophets had existed $^{30}$. One group admitted the possibility, while another rejected the ability of women to receive prophetic inspiration. Ibn Hazm sided with the former, since it bolstered his opposition to the existence of saints. In essence, those who asserted that saints could perform miracles cited the example of Mary, who appears in the Qur'an as the receiver of a miracle: since Mary was not a prophet, they argued, her case proved that others besides the prophets could receive from God the gift of miracles. The religious scholars who rejected the miracles of saints- Ibn Hazm among them- countered that Mary was indeed a prophet. In the background of this curious polemic was the emergence of charisma as a basis for new kinds of not only religious but also political authority.

Although asceticism and piety are documented in al-Andalus from a very early date, it is only beginning in the $4^{\text {th }} / 10^{\text {th }}$ century that mystic and Sufi trends properly understood began to proliferate. We have some texts from this period, such as those by Ibn Masarra (d. 319/931) ${ }^{31}$, and thanks to them and other sources we are able to sketch some characteristics of these trends:

\footnotetext{
${ }^{27}$ On these figures, see the studies by García Arenal and Fierro mentioned in notes 2 and 3.

28 Ibn Hazm, Kitāb al-fișal fi l-milal wa-l-ahwā' wa-l-niḥal (in the margins al-Milal wa-l-niḥal by alShahrastānī), 5 vols. in 1, Cairo, 1347-8H, vol. IV, p. 21, 138, 170-171, translated in M. Asín Palacios, Abenházam..., vol. IV, p. 175 and vol. V, p. 55, 140-141; Arthur Stanley Tritton, "Ibn Hazm: the man and the thinker", Islamic Studies 3 (1964), p. 471-484, p. 480.

${ }^{29}$ He approached this topic by addressing three questions: a) the polemic about who is the best Muslim and whether it is possible to be a better Muslim than the Prophet Muhammad (Ibn Hazm, Kitāb al-fișal..., vol. IV, p. 126-129, 150, 169-171 and vol. V, p. 14-18, translated in M. Asín Palacios,Abenházam..., vol. V, p. 21-25, 88, 138-141 and 182-184); b) the polemic with the Ash'aris over whether the miracles of the Prophet are proof of the truth of his prophetic mission (Ibn Hazm, Kitāb al-fișal..., vol. IV, p. 164, translated in M. Asín Palacios, Abenházam..., vol. V, p. 124); and c) the polemic over whether men who are not prophets can perform miracles that alter physical nature (Ibn Hazm, Kitāb al-fișal..., vol. V, p. 2-11, translated in M. Asín Palacios, Abenházam..., vol. V, p. 147-175; p. 150 of the translation makes reference to a supposed miracle that was proclaimed by the Jews of al-Andalus). He also tells us how he exposed the deceptions of a fraudulent miracle worker: Ibn Hazm, Kitāb al-fișal..., vol. I, p. 89-90; translated in M. Asín Palacios, Abenházam..., vol. II, p. 228-229.

${ }^{30}$ Ibn Hazm, Kitāb al-fișal..., vol. V, p. 12-14, translated in M. Asín Palacios, Abenházam..., vol. V, p. 175180. This polemic has been studied by Abdel Magid Turki, "Femmes privilégiées et privilèges féminins dans le système théologique et juridique d'Ibn Hazm" in Théologiens et jurists..., p. 101-58; Maribel Fierro, "The polemic about the karāmāt al-awliyā' and the development of Șūfism in al-Andalus (4th/10th-5th/11th centuries)", Bulletin of the School of Oriental and African Studies 55 (1992), p. 236-249.

${ }^{31}$ On this figure, see Historia de los Autores y Transmisores Andalusies (HATA), ed. Maribel Fierro, 2014, section XIII, no 4, online, http://kohepocu.cchs.csic.es/register/to/hata_kohepocu/ [Last accessed: 29/12/2015]. The most recent study is by Michael Ebstein, Mysticism and philosophy in al-Andalus. Ibn Masarra, Ibn al-'Arabī and the Ismā'īi tradition, Leiden, Brill, 2014.
} 
the belief in the miracles of saints (karāmāt al-awliy $\bar{a}^{\prime}$ ), that saints could surpass the prophets, that saints could be excused from fulfilling religious commandments and even commit prohibited acts, that they saw God and could converse with him, and that the possibility existed of attaining prophecy through spiritual perfection ${ }^{32}$. Ibn Hazm personally met a Sufi named Muhammad b. 'Isā of Elvira, who asserted that the Prophet was not obliged to comply with compulsory almsgiving (zakāt), because the servants of God were exempt from such payments and in consequence neither bequeath nor inherit. Ibn Hazm describes him as "an ascetic who lived apart from the world and a homiletic preacher who delivered formless and rambling sermons, with little skill and many errors". Ibn Hazm was concerned principally about the influence that such figures had among the people: regarding one occasion when he stopped to hear the preaching of this Muhammad b. 'Īsā, he says, "I refrained from disproving him, because the people (al'ämma) were there, and I feared that they would be roused to anger and knock me down"33.

But it is especially his description of an esoteric (Bāținī) community established in Pechina and inspired by Ibn Masarra in which we clearly perceive the political-military potential that these kinds of personalities could have ${ }^{34}$. The leader of the community was Ismā'il b. 'Abd Allāh al-Ru'aynī, whose doctrines show clear Bāținī cosmological influences: he declared that the Throne of God was the Being that ruled the cosmos, for God was too sublime to be attributed any action; he denied the resurrection of bodies; and he affirmed that the world would exist as it was indefinitely, as well as that the gift of prophecy could be acquired by spiritual purification and cleansing. The disciples of Ismā'îl al-Ru'aynī proclaimed that he knew the language of birds and could predict the future. They considered him their imām, to whom all Muslims owed obedience and should pay the obligatory alms (zakāt); given that unlawfulness extended to all things on Earth, the only thing that Muslims should possess was their daily sustenance; all of Earth belonged to the infidel, whose blood it was lawful to spill and whose property it was permitted to take - with the exception, obviously, of the belongings of the followers of the $i m \bar{a} m^{35}$. The political and even military implications - though they might be only potential - are clear: taxes were due to the imām of the Masarri community, who was also to be obeyed; any property not belonging to the community was illicit whatever its origin; and whosoever was outside of said community was subject to attack by it, since killing them and taking their property were permitted. We do not know if the members of this community in fact acted on these principles or what happened to them in the end, though surely the community must have died out as a result of the disaffection of its members, since Ismā'îl b. 'Abd Allāh al-Ru'aynī's doctrines came to be considered as too extreme for even some of his followers.

In any case, it was not the only community with these doctrines or closely related ones. Abū 'Umar al-Ṭalamankī (d. 428 or 429/1037), a native of Ṭalamanca (near Madrid), was a member of the same Yemeni tribe as Almanzor and had ties to the 'Âmirid family just like Ibn Hazm- whose teacher he was - but in contrast to Ibn Hazm, he had devoted himself to religious learning from his youth onward ${ }^{36}$. Also unlike Ibn Hazm- who was to a large extent self-taught

\footnotetext{
${ }^{32}$ In this section, the material is adapted from Maribel Fierro, "La religión" in Historia de España fundada por R. Menéndez Pidal y dirigida por J.M. Jover, vol. VIII/1: Los Reinos de Taifas, coord. Maria Jesus Viguera, Madrid, Espasa Calpe, 1994, p. 399-496.

33 Ibn Ḥazm, Kitāb al-fișal..., vol. IV, p. 155, translated in M. Asín Palacios, Abenházam..., vol. V, p. 102. Ibn Hazm had occasion to hear him in Almería.

${ }^{34}$ Ibn H.̣am, Kitāb al-fișal..., vol. IV, p. 151-152, translated in M. Asín Palacios,Abenházam..., vol. V, p. 9193.

${ }^{35}$ Ibn Ḥazm, Kitāb al-fișal..., translated in M. Asín Palacios,Abenházam..., vol. IV, p. 247-249 and vol. V, p. 91-93, as well as the study by Miguel Asín Palacios, Abenmasarra y su escuela. Orígenes de la filosofía hispano-musulmana, Madrid, E. Maestre, 1914, p. 92-106.
}

36 On this figure, see HATA, ed. Maribel Fierro, sección V, no 149, online, http://kohepocu.cchs.csic.es/register/to/hata_kohepocu/ [Last accessed: 29/12/2015]. The material here is taken from my conclusions in Maribel Fierro, "El proceso contra Abū 'Umar al-Ṭalamankī a través de su vida y de su obra", Sharq al-Andalus 9 (1992), p. 93-127. 
and who never travelled outside the Iberian Peninsula- al-Talamankī left al-Andalus for his studies, was trained in the foundations of law (ușül al-fiqh), and he took an interest in other disciplines that did not attract much attention among the scholars of his day in al-Andalus, such as non-rationalist theology (ușūl al-diyānāt). He was also a prominent representative of a kind of mysticism that was non-extremist but that went beyond the asceticism accepted by the legal scholars. In effect, on the one hand he refuted Ibn Masarra and the Bāținis, accusing the former of having arrogated to himself the gift of prophecy; on the other, he defended the possibility and the existence of the miracles of saints. He authored a work on asceticism that unfortunately appears to have been lost, although we can deduce that it proposed a code of conduct based on the life of the Prophet. Al-Talamanki's name appears as one of the intermediate links in a mystic chain of transmission extending from al-Ḥasan al-Basrī, through Fuḍayl b. 'Iyāọ, to the Andalusi mystic Ibn al-'Arî́ ${ }^{37}$. Al-Talamankī must have abandoned the capital of the Umayyad caliphate in $403 / 1012$, the year the Berbers entered the city, and like so many of his contemporaries, wandered between various cities in al-Andalus, visiting Almería, Murcia and Zaragoza, all of which were capitals of Taifa kingdoms connected to the group of 'Āmirid clients. In Zaragoza, a group of fuqah $\bar{a}^{\prime}$ and distinguished personages, among them Umayyad clients, testified against him, accusing him of heresy (khiläf al-sunna) and of having principles similar to those of the early Khawārij (the Harūrī). These included assenting to the indiscriminate spilling of blood, that is, believing that the need to combat innovators excused the killing of virtuous people in the course of battle. The qāọī of Zaragoza threw his full support behind al-Talamankī, convincing the other fuqah $\bar{a}^{\prime}$ to recuse the witnesses and finally declaring him innocent. This took place in the year $425 / 1034$, at a time when the Tujibids, kings of Taifa kingdom of Zaragoza, still acknowledged the last Umayyad caliph of Córdoba, Hishām III al-Mu'tadd, who had taken refuge in Lérida ${ }^{38}$. After being acquitted, al-Ṭalamankī returned to Talamanca, where he dedicated the remainder of his life to ribāt activities (pious retirement to concentrate on devotional and military practices in a frontier area). Although we do not have all of the necessary information for understanding precisely what his doctrines were, al-Talamankī seems to have come to believe that the imām should be a community's best Muslim. Such a view might have given rise to the accusation against him of sympathizing with the Khawārij, who also settled the question of who should assume leadership of a community in this way ${ }^{39}$. And that is not all: one text that remains quite obscure seems to suggest that a group of followers taking the form of a community (jamán'a) had gathered around al-Talamankī, who was recognized as its leader and was given the title of "first of the community" (awwal al-jamā'a). If we are interpreting this text correctly, we would have here an indication that the religious authority of these kinds of militant ascetic and mystical figures could give rise to political leadership. This is a development that will emerge unambiguously in al-Andalus after the death of Ibn Ḥazm in the figure of the Bāținì Abū I-Qāsim Aḥmad b. al-Ḥusayn b. Qasī (d. 546/1151) (0. $^{\circ}$

\footnotetext{
${ }^{37}$ Ibn Ḥazm, Kitāb al-fișal..., translated in M. Asín Palacios, Abenházam..., vol. IV, p. 247-249 and vol. V, p. 91-93.

${ }^{38}$ Abū 'Umar al-Ṭalamankī penned an epistle to the people of this city, which unfortunately has not been preserved: in it he may have incited them to fight to restore the Umayyad caliphate in the person of its last representative and urged them to undertake a kind of militant activity that disposed of the customary rules of combat. On these rules, see Khaled Abou El Fadl, "The rules of killing at war: an inquiry into classical sources", The Muslim world 89-2 (1999), p. 144-157.

${ }^{39}$ This is not necessarily incompatible with his possible support for Umayyad legitimism (see previous note): Hishām III al-Mu'tadd arrived in Córdoba humbly dressed and without any pomp, which I believe should be understood as an attempt by him to combine his pedigree with the image of an ascetic; in other words, he was fit to govern not only because he was an Umayyad but also because he possessed the attributes of piety and devotion.

40 On this figure, see HATA, ed. Maribel Fierro, section V, no 364, online, http://kohepocu.cchs.csic.es/register/to/hata_kohepocu/ [Last accessed: 29/12/2015].
} 
Ibn Qasī, born in Silves, was of muwallad (local convert) origin and had worked as a tax collector for the Almoravids. A spiritual crisis led him to give up this work, sell his possessions, give away the proceeds in alms, and devote his life to austerity. He travelled for a time around al-Andalus but never left the Iberian Peninsula and ended up founding a rābița near Silves, where his followers, the murīdūn or Sufi novices, congregated. In Șafar 539/August 1144, the Sufi Ibn Qasī staged a rebellion in the Algarve region leading an army that he had formed from the ranks of his novices. His objective was to oppose the Almoravids, Șanhāja Berbers who from their bases in the Sahara had conquered the southern part of Morocco and founded the city of Marrakech, and from there had spread northward. Having been invited by the Taifa kings to combat the Christians in al-Andalus, the Almoravids eventually overthrew those kings and installed themselves as the new rulers. But the combination of excessive taxation and the Almoravids' inability to stem the military advances of the Christians led the Andalusis little by little to reject the legitimacy of the new government. Ibn Qasī's movement was part of this rejection, but after a year in power, he was unseated by a political-military leader, Ibn Wazīr, who did not claim any religious leadership role. Ibn Qasī then set out for North Africa, where he sought the support of the Almohads. Having no choice but to recognize Ibn Tūmart as mahdī, he assisted the Almohads in their occupation of the peninsula. They then appointed him governor of Silves. Later, he attempted to break away from them by allying himself with the Christians. His followers apparently disapproved of this change in alliances and killed him in 546/1151. Little is known about Ibn Qasi's teachers, but we do know that he had contact with the two most important Sufi thinkers of his day, Ibn al-'Arîf of Almería and Ibn Barrajān of Seville. Although he has been associated with al-Ghazālī, his work, the Kitāb khal' al-na'layn, shows that he was a Bāțini thinker close to the Ikhwān al-Ṣafā' and the Ismā'ilīs, though it cannot be said that he subscribed to classical Sufi thought ${ }^{41}$. Again we find in his work various Bāținī cosmological concepts: God and man were originally united and then separated by creation, though they still remain united by the hidden reality of truth that one must attempt to attain. Although a series of spiritual exercises are prescribed, no mention is made of specific stages as with the Sufis. As the initiate succeeds in destroying his selfish desires, prayer becomes less and less necessary. For those that attain the Truth, prayer is irrelevant. His doctrine also has strong eschatological themes. He performed miracles, such as making an overnight journey to Mecca, was able to speak in silence and make his desires known, and possessed a supernatural treasure, which first produced Almoravid coins and later his own currency. He taught that an infallible imām (imām ma'șūm) was so not because of his genealogy, and was legitimate not on account of his efficacy, but due to the qualities of his character. According to Ibn al-Abbār, he called himself al-imām and was endowed with guidance (hidāya). Ibn Qasī referred to himself and his followers as "strangers" (ghuraba $\left.\bar{a}^{\prime}\right)^{42}$. The purpose of militarizing his movement was to overthrow the established Almoravid government through armed struggle. It was easier for a movement like the one launched by Ibn Qasī, which led to an armed rebellion against the Almoravids, to develop outside of the cities ${ }^{43}$, in rural areas where traditional fuqahä' exercised less religious control and where the state apparatus exercised less political-military control.

As for Ibn Barrajān and Ibn al-'Arïif ${ }^{44}$, they were summoned to Marrakech by the Almoravid emir in the year 536/1141 and died shortly thereafter under shady circumstances.

\footnotetext{
${ }^{41}$ As was shown by Michael Ebstein, "Was Ibn Qasī a Șūfi??", Studia Islamica 11 (2015), p. 196-232.

${ }^{42}$ On all of these points, see Josef Dreher, "L'imamat d'Ibn Qasī à Mértola (automne 1144-été 1145): Légitimité d'une domination soufie?", Mélanges de l'Institut Dominicain d'Études Orientales 18 (1988), p. 195-210; Vincent Lagardère, "La Tarīqa et la Révolte des Murīdūn en 539H/1144 en Andalus", Revue de l'Occident Musulman et de la Méditerranée 35 (1983), p. 157-170, p. 165-166.

${ }^{43}$ Pierre Guichard, Les musulmans de Valence et la Reconquête (XIe-XIII siècles), Damascus, Institut français de Damas, 1990-1991, vol. I, p. 106. 2 vols.

${ }^{44}$ On these two figures, see HATA, ed. Maribel Fierro, 2014, section V, nos 323 and 324, online, http://kohepocu.cchs.csic.es/register/to/hata_kohepocu/ [Last accessed: 29/12/2015].
} 
One source from the $7^{\text {th }} / 13^{\text {th }}$ century attests that Ibn Barrajān was considered an imām in 130 towns, which could be an indication only of his spiritual leadership rather than of a political rebellion ${ }^{45}$. But even if his imamate were only religious, his widespread influence-proof of which is provided by the letters that Ibn al-'Arif addressed to him- must have been seen as dangerous by the political powers at a time when the Almohads were threatening the Almoravids in the Maghreb. The Sufi master possessed certain moral qualities that the religious scholars and fuqah $\bar{a}^{\prime}$ were thought to lack, because of their close contacts with the political rulers, which affected their legitimacy as interpreters of divine law. At the same time, the Sufi master held forth the possibility of a more direct kind of contact between the creator and his creatures; in other words, he possessed a charisma that could be seen as a threat to the Prophet's charisma ${ }^{46}$.

\section{The Law and the Qādī}

Ibn Qasī rejected both reason and law (fiqh) and asserted that prophecy needed to be revitalized periodically by saintliness, a stance that did not win him the support of the fuqah $\bar{a}^{\prime}$. Part of Andalusi society reacted to Ibn Qasi's rebellion and declining confidence in the Almoravids by handing political and military power over to the judges or qāọis. Ibn al-Abbār defined the period between the fall of the Almoravids and the Almohad conquest as a time when the judges gained power in al-Andalus, both in the east and in the west (ta'ammarat al-qudāt fi bilādiha sharq $\left.{ }^{a n} w a-g h a r b^{a n}\right)^{47}$. The rule of the judges who seized power in Córdoba, Jaén, Málaga, Murcia and Valencia was ephemeral, but for a time they were successful in confronting the Almoravids and even raising armies. The most important of them was Ibn Hamdin in Córdoba, who took the titles of al-Manșūr bi-llāh and amìr al-musliminn (Christian chronicles refer to him as "king"), minted currency, and was able to recruit an army. His government was in power for eleven months.

The qā dīs who gained power during the transitional period between the Almoravids and the Almohads had a precedent in the $5^{\text {th }} / 11^{\text {th }}$-century qãdīs who not only gained power during the disintegration of the Umayyad caliphate (fitna) but even in some cases established local dynasties that were relatively long-lasting, as happened in Silves, Toledo and especially Seville. Let us take a brief look at these two cases, whose protagonists were contemporaries of Ibn Hazm and, in the case of Seville, might even have met him in person.

In Toledo, Ya'īsh b. Muhammad al-Asadī - the son of Abū 'Abd Allāh Muḥammad (d. $391 / 1000$ or 393/1003), an expert in Mālikī legal literature and in contracts and a member of an important family in Toledo (min bayt 'ilm wa-jalāla wa-ri'āsa)- took power. His father Muhammad had been a muftī along with Sa'īd b. Ahmmad b. Sa'īd b. Kawthar al-Anșāī (d. ca. 400/1009), who is described as an intelligent and wealthy person. Ya'īsh b. Muhammad studied masā'il with his father and two other Toledo teachers; he also studied in Córdoba and North Africa with a famous Mālikī jurist, Ibn Abī Zayd al-Qayrawānī. After the death of Muhammad b. Ya'īsh and Sa'īd b. Kawthar, the ri'āsa of Toledo was passed on to Ya'īsh and to a son of Sa'īd, named Abū 'Umar Ahmad (d. 403/1012), also famous for his wealth and the splendid treatment

\footnotetext{
${ }^{45}$ A recent analysis of this question with references to previous studies is that by José Bellver, "'Al-Ghazālī of al-Andalus': Ibn Barrajān, Mahdism and the emergence of learned Sufism on the Iberian Peninsula", Journal of the American Oriental Society 133-4 (2013), p. 659-681. On Ibn Barrajān see now Yousef Casewit, The Mystics of al-Andalus: Ibn Barrajān and Islamic Thought in the Twelfth Century, Cambridge, Cambridge University Press, 2017.

${ }^{46}$ On this subject, see Javier Albarrán, El Profeta: veneración y polémica. Muhammad en el cadi 'lyāọ (s. XII), Madrid, Ediciones de La Ergástula, 2015.

${ }^{47}$ What follows is based on Maribel Fierro, "The qāọī as ruler", in Saber religioso y poder político. Actas del Simposio Internacional (Granada, 15-18 octubre 1991), Madrid, Agencia Española de Cooperación Internacional, 1994, p. 71-116 and P. Guichard, Les musulmans de Valence..., vol. I, p. 107-108, 114. See now Fukuzo Amabe, Urban autonomy in Medieval Islam. Damascus, Aleppo, Cordoba, Toledo, Valencia and Tunis, Leiden, Brill, 2016, p. 85-117.
} 
he gave to his disciples. Ya'īsh surpassed him in religious learning ('ilm). The ri'āsa seems to refer to the judicial sphere, since Ya'īsh and Ibn Kawthar were in charge of judicial sentences (ahkām) in Toledo. At the beginning of the fitna (400/1009-403/1012), the government was controlled by a Toledan named Ibn Masarra ${ }^{48}$, who showed a preference for Ya'īsh and sent Ahmad b. Kawthar into exile in Santarém, where Ibn Masarra had him killed in 403/1012. When, at an unknown date, Ibn Masarra died, Ya'īsh was left as the sole ruler of Toledo (șāra ilayhi tadbīr al-ri'āsa). He expelled one of Ibn Masarra's sons from the city, proof that he did not intend to share power with anyone. The historian Ibn Ḥayyān portrays him in a very positive light, saying that he protected religion in Toledo and excelled at governing. Another source describes him as virtuous, upright, and very wise, and mentions that he promoted the practices of $j i h \bar{a} d$ and pilgrimage and spent lavishly for God (fi l-sabīl); he recited the Qur'an and prayed frequently. Ya'ish never adopted the title of ra'iss, preferring to keep the title of faqīh, and dressed in the style of the religious scholars. He did designate his son 'Abd Allāh as ra'îs of Toledo, a move that indicates that he intended to keep power in the family. As faqīh and $q \bar{a} d \underline{i} \bar{i}$, Ya'īsh was famous for his severity (shidda): he prohibited women from attending funeral processions and banned the milling of a highly refined flour called darmak. The former prohibition was related to the fact that cemeteries were one of the places where men and women mingled and might have dealings with one another. The latter prohibition seems to have targeted the wealthier inhabitants of the city, the only ones who would have been able to afford this product. These two prohibitions probably didn't make him very popular. The people of Toledo tired of his government, executed his son (the one to whom he had given the title of $r^{\prime}{ }^{\prime} \overline{i s}$ ), and deposed Ya'īsh in 417/1026. He went to Calatayud, where he died in $418 / 1027,419 / 1029$ or $427 / 1035$. He had governed for fourteen years. Toledo's reaction to the fitna was, therefore, to give power to local families, whose prestige derived from their wealth and 'ilm. Religious learning ('ilm) which was represented by Ya'īsh, ended up prevailing over wealth, represented by Ibn Kawthar. Ya'īsh attempted to dissociate the figure of the ra'îs from that of the qādī/faqīh, although the qādī was the one to name the ra'îs and was the de facto ruler. As qādīi, he attempted to raise the moral standards of society by prohibiting certain practices that affected women's freedom of movement and the market. There is no evidence of anything comparable to this in other places where judges became rulers, so possibly his attitude should be understood in the context of the documented pietism in Toledo and the surrounding region, a ribāt area where the preceptal-amr bi-I-ma'rüf wa-l-nahy 'an al-munkar was taken seriously ${ }^{49}$. The pietists in Toledo might have supported the rise to power of a figure like Ya'īsh, a strict Mālikī faqīh who tried to make his society conform to his interpretation of what constituted correct Islamic conduct. The people of Toledo, however, once they had a taste of those policies, got fed up and eventually offered power to a man of the sword, the Berber Ibn Dhi I-Nūn who had the support of an important local family, the Banū IHadīdi, who not only seem not to have had pietist inclinations but were also characterized by their support for specialists in the non-Islamic sciences ${ }^{50}$.

As for Seville, during the period of Hammudid control, the city's qāḍi was Abū I-Qāsim Muhammad b. 'Abbād (d. 433/1041), whose father, Ismā'īl (d. 410/1019), had been appointed qāọī by Almanzor and was a member of a family said to own a third of the lands in Seville. In 414/1023, when the caliph al-Qāsim b. Hammūd sought refuge in Seville after having failed in his

\footnotetext{
${ }^{48}$ This is not the same person as the thinker mentioned in the previous section.

${ }^{49}$ Manuela Marín, "Los ulemas de Toledo en los siglos IV/X y V/XI", in Entre el Califato y la Taifa: Mil años del Cristo de la Luz. Actas del Congreso Internacional. Toledo 1999, Toledo, Asociación de Amigos del Toledo Islámico, 2000, p. 67-96 and "Ulemas en la Marca Media", in Estudios Onomástico-Biográficos de al-Ándalus, vol. VII: homenaje a José María Fórneas, ed. Manuela Marín and Helena de Felipe, Madrid, CSIC, 1995, p. 203-230.

50 Isabel Toral, "Yahyà b. al-Ḥadīdī, un notable en la corte de los Dū I-Nūn de Toledo", in Estudios onomástico-biográficos de al-Andalus. vol. VI: homenaje a José María Fórneas, ed. Manuela Marín, Madrid, CSIC, 1994, p. 395-414.
} 
attempt to take Córdoba, he was denied entry, and the judge Abū I-Qāsim seized power, at first sharing it with other prominent citizens. Later, in 418/1027, a member of the Hammudid dynasty, Yahyā b. 'Alī b. Hammūd, tried to capture Seville, and its inhabitants opted not to resist and instead agreed to pay him a large sum of money and recognize his sovereignty in exchange for a promise not to allow the Berbers to enter the city. The Hammudid caliph accepted these terms and requested hostages. The qāọi Abū I-Qāsim was the only person to respond to this request and handed over his son 'Abbād, which only enhanced his popularity. The caliph named him governor of Seville, and the city's inhabitants agreed to obey him. From that point on, he was the true master of the city and stripped power from those who had previously shared it with him, in some cases even expelling them from Seville and confiscating their property. The monies that were no longer paid in tribute to Córdoba were used to raise a mercenary army. In 427/1035, when Yahyā b. 'Alī b. Ḥammūd attempted to reconquer Seville but was defeated and killed, Abū I-Qāsim b. 'Abbād produced a false Umayyad caliph whom he tried to pass off as Hishām II al-Mu'ayyad. He had the Friday sermon given in his name and tried to convince the other Taifas to recognize his rule. This was an attempt to reconstruct the system that had existed under Almanzor. Abū I-Qāsim b. 'Abbād was succeeded by his son Abū 'Amr 'Abbād (433/1042461/1068), who went by the title of chamberlain (al-hājib) - like Almanzor - and later by a quasicaliphal title, al-Mu'taḍid; both titles appear on the coins that he minted. The false Hishām died sometime during his reign and his death was kept secret until 452/1060. That year al-Mu'tadid ordered his own name to be declared in the Friday sermon. He was succeeded by his son Abū IQāsim Muhammad (461/1068-484/1091), who reigned as al-Mu'tamid and on whose coins alimām 'abd Allāh amìr al-mu'minin is mentioned, which I understand as an acknowledgement of the idea of the caliphate without making explicit which caliph is being referred to. While Ismā'îl - the qāọī appointed by Almanzor - had an intellectual background as a faqīh, his son Abū IQāsim b. 'Abbād served in the post more for political reasons than because of his training. In contrast to what happened in Toledo, in this case wealth was more important than 'ilm. Unlike Ya'īsh, Abū I-Qāsim b. 'Abbād did not attempt to dictate morals and perhaps for that reason he was able to found a dynasty.

These judges, as has already been mentioned, tended to be members of important local families, their prominence deriving from wealth or learning, or more often a combination of both, in addition to experience in the city government through serving as judges. One might think that the absence of institutionalized autonomous government in the towns encouraged the qāọiss to seize power at times when governmental authority was waning. Although judges were theoretically chosen by the ruler, in practice the choice was generally made from among the prominent inhabitants of a city, and often the latter determined who was elected. This does not mean that, during periods when the ruler's authority was in decline, there was necessarily a qāḍi government: there are ample examples to the contrary. There were cities where the position of qāọi was virtually hereditary among powerful local families and yet they did not seize power during the fitna; qāọīs sometimes remained loyal to the previous authorities or swore obedience to new ones. In other words, a qāḍi government was only one possibility among many, since power could end up in the hands of governors, military leaders, or viziers. This range of possibilities is what characterized the fitna period that gave rise to the Taifa kingdoms. The position of qāḍi, however, had some important advantages: the qāọī was - according to Islamic political-legal theory - the delegate of the caliph or the sulțān. As a religious scholar he was also a delegate or $n \bar{a}^{\prime} i b$ of the Prophet. This is clear from the Risāla fi l-qaḍa' wa-I-hisba by the Sevillian Ibn 'Abdūn, from the Almoravid period, in which we see a tendency to increase the qāḍī's power. Ibn 'Abdūn - in addition to specifying that qāḍis and other magistrates should be of Andalusi origin because this allows them to better understand the concerns of the population and its different social groups - asserts that the judge should control the other authorities - tax collectors and the vizier (wazir al-dawla) - as well as attend to the affairs of the government and of the agents of the state (umūr al-sulțān wa-l'ummāll). Good government depends on the judge, 
since the prince ( $\left.r a^{\prime} \bar{i} s\right)$ must consult the judge and the fuqaha'. For Ibn 'Abdūn, who mentioned neither the caliph nor the imām, the judge is the custos who at the same time custodiet custodes. Ibn 'Abdūn considered his day to be a period of such extreme corruption (fasād) and disorder (harj) that only a prophet would be able to restore order with the help of God. However, since it was not a time of prophets (recall that Muhammad was the last of the prophets), the only person qualified to put things in order was a judge (wa-lā yușlihu hādhihi l-umūr illā nabī bi-idhn Allāh fa-in lam yakun zaman nabī fa-l-qāọī mas'ūl 'an dhalika kullihi) ${ }^{51}$.

\section{Why Ibn Ḥazm Became a Ẓāhirī}

We have seen how Ibn Hazm's anti-charismatic stance can be explained by the context of his times, when the Umayyads' greatest enemy was the Fatimids, whose caliphate was based on charismatic leadership and Messianism, and when the crisis of Umayyad legitimacy and the development of Muslim society itself encouraged a search for new political and/or religious authority figures. The allure of some of these charismatic figures was based not so much on assuring the implementation and continuity of the Law founded on the Revelation given by God to an Arab prophet - which was fundamentally the model of the Sunni Umayyad caliphate in Córdoba - as on their presenting themselves as inserted into a cosmological worldview that made them a kind of mediators between Creator and creation, as well as on the fact that they seemed to promise various means of communicating with the Divinity. That is precisely why charismatic, messianic, and/or saintly figures had potential for political leadership - as well as military leadership, on account of the devotion that they inspired in their followers - which might not ever materialize, but was always latent. We have also seen how judges - as representatives of rulers who appointed them and linked to the Divinity, since it was they who were charged with implementing a law that had been enacted by God - were also potential political figures. In contrast to the rural spheres of influence of some of the other figures (such as the saints and "false" prophets), the political potential of judges was strongest in urban centers, where the figure of the 'álim- a specialist in religious learning - was also well established. In times of political fragmentation and disorder, the qāọi of an Andalusi city could come to fill the power vacuum left by the latest failed ruler and even to found a local dynasty. These qāọis usually represented the prominent inhabitants of the cities, but they also succeeded in attracting the support of the general population, who saw in them protectors of a political order based on the sacred, as well as loyal enforcers of religious law (sharîa), which many Muslims throughout history have seen as a check against the tyranny of rulers precisely because it is a law that was not formulated by them. These qāọis assumed titles that were sometimes reminiscent of the caliphs, but they maintained the fiction of ruling in the name of a caliph, though the latter was absent or no one knew exactly who he was.

During his lifetime, Ibn Hazm witnessed some of these qāọīs rise to power, including those in Silves, Toledo, and especially Seville. We do not have any evidence that he disapproved of this development, other than the fact that it was made possible by the disintegration and disappearance of the Umayyad caliphate that he considered the legitimate government of alAndalus. When he settled in Seville after having been driven out of other cities due to the aversion he inspired in some Mālikĩ fuqahă', Ibn Hazm seems to have wanted to secure some measure of stability, and to that end he may have introduced a series of changes into his first draft of his work al-Fișal, such as his decision not to attribute directly to himself the doctrine

\footnotetext{
${ }^{51} \mathrm{Ibn}$ 'Abdūn, Risāla fĩ l-qaḍā' wa-l-ḥisba, in Thalāth rasā'il andalusiyya fĩ ādāb al-ḥisba wa-l-muhtasib, ed. Évariste Lévi-Provençal, Cairo, Institut français d'archéologie du Caire, 1955, p. 1-65; translated in Emilio García Gómez and Évariste Levi-Provençal, Sevilla a comienzos del siglo XII. El tratado de Ibn 'Abdūn, Sevilla, Servicio de Publicaciones del Ayuntamiento de Sevilla, 1981, p. 60/182-183, parag. 230.
} 
sanctioning rebellion against an unjust $i m \bar{a} m^{52}$. It didn't do him much good, though, since he ended up being expelled from the city anyway. The 'Abbādids maintained the fiction of continuity with Umayyad legitimacy by way of acknowledging the false Hishām II, a imposture that Ibn Hazm had denounced in his work Naqt al-'arūs in a passage that is said to have provoked the ire of the king of Seville when Ibn Hazm's enemies called it to his attention, leading al-Mu'tadid to order Ibn Hazm's works to be publicly burned ${ }^{53}$. According to a different source, Ibn Sa'îd, the reason for the rift between the Sevillan king and Ibn Hazm was the polemic that the latter carried on with the Mālikī jurist and Ash 'arī theologian Abū I-Walīd al-Bājī (d. 474/1081) ${ }^{54}$. In any case, a kingdom that Ibn Hazm might have believed was going to afford him some respite closed its gates to him. As for Toledo, it is possible that he would not have been in agreement with the measures taken by its qādī, specifically the prohibition against the participation of women in funeral processions, since one of the points of disagreement between Ibn Ḥazm and his Mâlikī colleagues was precisely that he conceded greater freedom of access to public spaces to women, in particular allowing women to pray in the great mosques, to visit cemeteries, and to participate in funeral retinues ${ }^{55}$. The measures taken by the qāọi Ya'īsh therefore must have seemed illegitimate to him. And we should keep in mind that Ibn Hazm preferred to live in areas governed by the former members of the Umayyad-'Ämirid caliphal administration, so he never seems to have considered either Toledo or Zaragoza.

We have seen that Ibn Hazm was opposed to charisma but not to the law. Let's return to one of the questions we asked at the beginning. Why was Ibn Hazm opposed to the Māliki school? And why did he eventually choose Zāhirism as an alternative ${ }^{56}$ ? In my opinion and taking into account his career, Ibn Hazm rejected Mālikism because he considered it dangerous to concede the field of religious knowledge to the Māliki fuqaha $\bar{a}^{\prime}$. Such a monopoly of religious learning would allow them to present a unified opposition to the social group that he belonged to by birth and as a matter of culture, that of the Umayyad courtly administration (khidma). He was not alone in perceiving this danger: 'Abd al-Rahmmān III had sought to ensure some degree of plurality in the legal schools in his territory ${ }^{57}$, while Almanzor sought the support of Mālikī fuqah $\bar{a}^{\prime}$ with Shāfi'i tendencies in order to curb the influence of traditional Māliki fuqahāās8.

Ibn Hazm's opposition to the Mālikī school is usually attributed to his intellectual need for rationalism and coherence. Andalusi Mālikism was an heir - like Hanafism - to a particular stage in the development of jurisprudence in which personal opinion $\left(r a^{\prime} y\right)$ played a fundamental role: certain legal decisions were frequently justified by a simple appeal to authority, which could lead to conflicts with other decisions, and this exposed the fact that what had been legislated had not been consistently and coherently deduced from the revealed sources according to a

\footnotetext{
${ }^{52}$ S. Kaddouri, "Dissimulation des opinions...". On Ibn Ḥazm's position on this point, see Michael Cook, Commanding Right and Forbidding Wrong in Islamic thought, Cambridge, Cambridge University Press, 2000, p. 390, 511.

${ }^{53}$ In the Naqt al-'arūs, Ibn Hazm denounces the Umayyad caliph proclaimed by the 'Abbādids as an imposter and mentions the cruelty of al-Mu'taḍid: M. Asín Palacios, Abenházam..., vol. I, p. 230 and vol. II, p. 167-168.

${ }^{54}$ See note 24.

${ }^{55}$ Camilla Adang, "Women's access to public space according to al-Muhallā bi-l-Āthār", in Writing the Feminine: Women in Arab sources, ed. Manuela Marín and Randi Deguilhem, London, I.B. Tauris, 2002, p. 75-94. He also allowed women to lead other women in prayer, a doctrine that could possibly be related to what we know about the religious activities of a woman from the family of Córdoba's Berber qāḍi, Mundhir b. Sa'īd al-Ballūțī (d. 355/965): Manuela Marín, Mujeres en al-Ándalus, Madrid, CSIC, 2000, p. 625.

${ }^{56}$ On the evolution of Ibn Hazm's doctrine, see the study by Camilla Adang mentioned in note 15.

57 Maribel Fierro, "Los cadíes de Córdoba de 'Abd al-Raḥmān III (r. 300/912-350/961)", in Estudios Onomástico-Biográficos de al-Andalus, vol. XVII: Cadíes y cadiazgo en el Occidente islámico medieval, ed. Rachid El Hour, Madrid, CSIC, 2012, p. 69-98.

58 This was the case of al-Așili (d. 392/1002): HATA, ed. Maribel Fierro, 2014, section III, no 245, online, http://kohepocu.cchs.csic.es/register/to/hata_kohepocu/ [Last accessed: 29/12/2015].
} 
rigorous methodology. This practice, moreover, led to a proliferation of divergent opinions that could be dismissed as lacking a solid foundation. Mālikism originated with the charismatic figure of Mālik b. Anas (d. 179/795) and his disciples ${ }^{59}$, a fact that was criticized by Ibn Hazm, who pointed out that Mālik was a mere mortal ${ }^{60}$. Later jurists attempted to systematize legal methodology, most prominently al-Shāfi'i (150/767-204/820), who established the foundations of law as the Qur'an, the Sunna or Tradition of the Prophet, consensus, and a disciplined form of reasoning called qiyās or analogy ${ }^{61}$. The Mālikīs of al-Andalus were generally opposed to these attempts at systematization, and so to confront them Ibn Hazm seems to have aspired to construct a legal-religious corpus that was perfectly coherent, to which end he created a method and principles that he seems to have applied in a systematic way, giving rise to a doctrine that combines logic, grammar, law and theology ${ }^{62}$.

But Ibn Hazm's need for systematicity and coherence could have led him- as it did others among his contemporaries- to become what I have called a reformed Mālikī, like Abū 'Umar b. 'Abd al-Barr (d. 463/1071), Abū I-Walīd al-Bājī and later Ibn Rushd al-Jadd (d. 520/1126), Ibn Ḥazm made the decision to reject Mālikism outright and subscribe to Ẓāhirism after a short Shāfi'̄ phase. This was a marginal movement, although it had had important adherents in al-Andalus, interestingly among people like him who were associated with the world of the court and Umayyad supporters ${ }^{63}$. Such was the case of Mundhir b. Sa'îd al-Ballūțī, a member of a Berber family who was appointed qāọi of Córdoba by 'Abd al-Rahmān III. Through this appointment the Umayyad caliph showed his aloofness toward the Fatimids: in opposition to their esotericism or Bāṭinism, he appointed a literalist or Zāhirī judge ${ }^{64}$.

Zāhirism is adherence to the doctrine of zāhir, that is, a conviction that the texts of the Revelation should be understood in their literal, external, or apparent meaning, without recourse to deductive methods such as reasoning by analogy, which can only introduce an element of human arbitrariness into the divine plan ${ }^{65}$. Zāhirism is characterized by strict adherence to the "letter" of religious law, without examining the reasons that might be behind a particular prohibition or authorization, behind lawfulness or unlawfulness. The literal interpretation of the Qur'an and the Hadith requires that, when a text has an imperative or prohibitive connotation, the Zāhiris must conclude that the act referred is in absolute terms obligatory (wājib) or prohibited (harām), without nuances. Now, the texts that clearly deal with obligations or prohibitions are relatively few in the Qur'an; and in the case of the Hadith or the Tradition of the Prophet, it is first necessary to establish whether a particular tradition is correct or not. All of this means that the topics covered by express formulations are very few, especially if one takes into account the rejection of reasoning by analogy or qiyās. Ibn Hazm's opposition to qiyās is based on the fact that its use is not mentioned anywhere in the Qur'anic text, that it leads to differences

\footnotetext{
59 Jonathan Brockopp, "Theorizing Charismatic Authority in Early Islamic Law", Comparative Islamic Studies 1-2 (2005), p. 129-58.

${ }^{60}$ Camilla Adang, "Restoring the Prophet's Authority, Rejecting Taqlïd: Ibn Hazm's 'Epistle to the One who Shouts from Afar'", in Religious Knowledge, Authority and Charisma: Islamic and Jewish Perspectives, ed. Daphna Ephrat and Meir Hatina, Salt Lake City, The University of Utah Press, 2013, p. 50-63, p. 280-283; S. Kaddouri, "Dissimulation des opinions...".

61 Ahmed El Shamsy, The canonization of Islamic law. A social and intellectual history, Cambridge, Cambridge University Press, 2013, p. 190-193.

62 See Roger Arnaldez, Grammaire et théologie chez Ibn Hazm de Cordoue. Essai sur la structure et les conditions de la pensée musulmane, Paris, Vrin, 1956, p. 26 and the collective volume cited in note 5.

63 The connection of Zāhirism with courtly contexts in the East has been pointed out by Christopher Melchert, The formation of the Sunni schools of law: $9^{\text {th }}-10^{\text {th }}$ centuries CE, Leiden, Brill, 1997, p. 178-197.

${ }^{64}$ See note 16.

65 Ignaz Goldziher, The Zāhirīs. Their Doctrine and their History. A Contribution to the History of Islamic Theology, translated by Wolfgang Behn, with an introduction by Camilla Adang, Leiden, Brill, 2008; Robert Gleave, Islam and literalism: literal meaning and interpretation in Islamic legal theory, Edinburgh, Edinburgh University Press, 2012.
} 
of opinion, and moreover that there are limitations to human reason ${ }^{66}$. In other words, the conclusions arrived at through rational argument cannot be placed on the same level as a revealed text. Reason has to be subject to Revelation: reason is capable of accepting the existence of God, but it is too limited to grasp His essence. There is also no need to inquire into the reasons why a particular law has been given, no need to wonder about the "causes" of divine law, since the only cause is the will of God ${ }^{67}$. For example: some of the verses of the Qur'an place a prohibition on the eating of pork, a prohibition without any rational basis but which must be obeyed without scrutinizing the reasons, merely because it has been revealed. Ibn Hazm's stance can be summarized in the following way: in matters that concern Revelation, truth is only that which has been explicitly established by God or the Prophet or that which consensus recognizes as such. With respect to ijm $\bar{a}^{\prime}$ or consensus, Ibn Hazm understands it in a limited sense: not all 'ulam $\bar{a}$ ' can be considered competent authorities on juridical questions that are not resolved by the Qur'an and the Tradition of the Prophet; only the consensus of the Companions of the Prophet has authority, and even this is difficult to ascertain ${ }^{68}$.

Going to the revealed or prophetic text is the only way to be sure that one is following God's will and to avoid subjective human interference in divine lawmaking ${ }^{69}$. Ibn Hazm's literalism leads him to reject the metaphorical interpretation developed particularly by Sufis and Shi is. His rejection of speculative elements is of a piece with his acceptance of using logical arguments, to the point of recommending that the works of Aristotle be employed to establish premises and arrive at correct deductions, formulate appropriate definitions and carry out other logical operations. Ibn Hazm's system, therefore, does not eliminate reason; rather, it has a rigorously defined and limited role and is subordinated to the teachings in God's message to humankind. Reason should be understood solely as the faculty of understanding necessary for properly fulfilling the commandments of God. For Ibn Hazm, logic is the system that allows him to analyze the revealed and prophetic texts in their literality without running the risk of replacing what God meant to say with what man wants Him to say ${ }^{70}$.

The result of all of this is a considerable curtailment not only of what is considered prohibited but also of the social and religious practices regulated by sharîa: in Zāhirism, the spheres of activity that are free from legal and religious regulation are more numerous than in other legal schools. This fact, in addition to the application of his methodology, often leads Ibn Hazm to some conclusions that conflict with other legal schools and others that are rather peculiar, as demonstrated by some of the cases that have been studied. Let us review some of those cases and as we do so I will indicate how Ibn Hazm's doctrinal and legal stance can be linked to the circumstances of his biography.

We have seen how Ibn Hazm takes his defense of the exceptionalism of the prophets to the extreme, claiming that they are the only ones capable of performing miracles: thus there can be no such thing as miracles produced by Shi i imams or saints (awliy $\bar{a}^{\prime}$ ), and the only acknowledged charisma is that of the Prophet. It has also been mentioned that Ibn Hazm concedes greater agency to women in the public sphere and considers them entitled to serve as

\footnotetext{
${ }^{66}$ All these reasons have been analyzed by Goldziher in his treatment of the work that Ibn Hazm wrote in explicit refutation of qiyās, Ibțāl al-qiyās wa-l-ra'y wa-l-istihsā̄n wa-l-ta'līl.

${ }^{67}$ I. Goldziher, Żăhirīs..., p. 41-42. In the spheres covered by Revelation, there are no acts that are good or bad in themselves, only insofar as they are or are not consistent with what God has ordained or prohibited: I. Goldziher, Z̄āhirīs..., p. 150-151.

${ }^{68}$ I. Goldziher, Z̦āhirīs..., p. 32, 34, 135; see also Marie Bernard-Baladi, L'accord unanime de la Communauté comme fondement des statuts légaux de l'Islam, Paris, Vrin, 1970.

${ }^{69}$ Abdel Magid Turki, "L’idée de justice dans la pensée politique musulmane: I’interprétation d'Ibn Ḥazm de Cordoue (456/1063)", Studia Islamica 68 (1988), p. 5-26, p. 10.

${ }^{70}$ See the articles by Rafael Ramón Guerrero and Joep Lameer included in the collective volume mentioned in note 5 .
} 
qāọīs. It is not only women who can serve in that capacity but also slaves ${ }^{71}$, who are therefore acknowledged to have a degree of agency that corresponds to the important role they played in the Umayyad-'Āmirid system. Ibn Hazm wrote an epistle in which he concluded that singing is "lawful, although abstaining from song is more praiseworthy, as is the case with all other superfluous but lawful things in the world, "because "when a man thus sets out to amuse his soul and channel it to strengthen his obedience to God ... that does not make him lose his way"72. Is it possible to imagine a court without poetry and song? Although he considers homosexuality

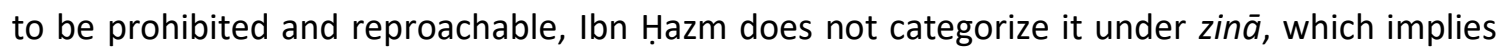
that those who engage in it cannot be sentenced with the death penalty or one hundred lashes; rather they are subject only to a discretional punishment (ta'zir). From his treatise on love and lovers and from many other textual references, we know that in the circles in which Ibn Hazm moved there were homosexual relationships and he was acquainted with those who engaged in them ${ }^{73}$. On the other hand, Ibn Hazm rejected the validity of a pronouncement attributed to the Prophet according to which legal sanctions established by God were not to be imposed in cases of doubt. It seems that this rejection would have led him to take an extremely severe stance on the imposition of such sanctions, but in fact this is not the case, as the following demonstrates: a man and a women who are on a journey have sexual relations and claim that they are married, but this is not known for a fact; nonetheless, their word must be accepted owing to the principle of inviolability (hurma $)^{74}$, which protects both Muslims and non-Muslims in their lives and property and which cannot be infringed unless there is absolute certainty, so that it is nobody's right to question the nature of the relationship that the couple claims to have. Only if there is evidence to the contrary can action be taken against them ${ }^{75}$. There is consequently no place for censors acting on their own account or for inquisitorial trials against those living in truly Islamic societies. Neither is there a place for paralyzing anguish over the fear of hell: Ibn Hazm offers believers, including sinners, wide-ranging prospects for salvation ${ }^{76}$.

Based on the cases that we have reviewed, we can say that Ibn Hazm conceived of a society without saints, but also without censors who interfere in the lives of others ${ }^{77}$. It was a social conception in which women and slaves could be qāọis, which implies an acknowledgement of their capacity to acquire the religious knowledge necessary for serving in that position; in which music is lawful and those who are especially religious can renounce it without imposing their own scrupulousness on others; in which the transgression of homosexuality does not lead to the death penalty; and above all in which intelligence, a capacity for understanding, and reason are the qualities that determine who is in charge of interpreting the law, which should not be in the hands of those who are content to imitate certain authorities from the past, elevating them above the rest. In other words, Ibn Ḥazm did not want to see a group of fuqah $\bar{a}^{\prime}$

\footnotetext{
${ }^{71}$ Alfonso Carmona, "Le malékisme et les conditions requises pour l'exercice de la judicature", Islamic Law and Society 7 (2000), p. 137-26.

72 Elías Terés, "La epístola sobre el canto con música instrumental, de lbn Hazm de Córdoba", Al-Andalus36 (1971), p. 203-214, p. 212-213; M. Asín Palacios, Abenházam..., vol. I, p. 263.

${ }^{73}$ Camilla Adang, "Ibn Ḥazm on Homosexuality. A Case-Study of Z̄āhirī Legal Methodology", Al-Qanțara 24 (2003), p. 5-31 and "Love between Men in Tawq al-ḥamāma", in Estudios Onomástico-Biográficos de alAndalus, vol. XIII: Identidades marginales, ed. Cristina de la Puente, Madrid, CSIC, 2003, p. 111-146. See also François Clément, "Les homosexuels dans l'Occident musulman médiéval: peut-on parler de minorité?", in Minorités et régulations sociales en Méditerranée médiévale, ed. Stéphane Boissellier, François Clément and John Tolan, Rennes, Presses Universitaires de Rennes, 2010. It has been said that Ibn Hazm himself felt the same tendencies.

${ }^{74}$ Birgit Krawietz, Die Hurma: Schariatrechtlicher Schutz vor Eingriffen in die Körperliche Unversehrtheit nach arabischen fatwas des 20. Jahrhunderts, Berlin, Duncker and Humblot, 1991.

75 Ibn Ḥazm, al-Muhallā, 11 vols. in 8, Cairo, 1348/1929, vol. XI, p. 242-244; Maribel Fierro, "Idra'ū l-ḥudūd bi-l-shubuhāt: when lawful violence meets doubt", Hawwa, 5-2/3 (2007), p. 208-238.

${ }^{76}$ Christian Lange, "Ibn Hazm on sins and salvation" in Ibn Hazm of Cordoba..., p. 429-454.

${ }^{77}$ See also M. Cook, Commanding Right..., p. 496.
} 
who were followers of legal schools like Mālikism granted authority independent of intellectual merit, because such authority could be used to promote certain doctrines that affected the lives of others, especially the social group to which Ibn Hazm belonged. Ibn Ḥazm's Z̦āhirism thus seems to be oriented to defend and protect the values and behaviors characteristic of this group, in two different senses. On the one hand, although this culture was sustained by a few prominent families, when an individual became truly distinguished it was on account of natural merit - such as "born" poets - or through effort. On the other hand, in that courtly culture, man - with all his longings, affections, imperfections, and desire for perfection - took center stage. Ibn Hazm devoted memorable pages to this view of man in his treatise on love, Tawq al-hamāma, and in his treatise on ethics, the Kitāb al-akhlāq wa-l-siyar ${ }^{78}$. In the latter work, he reminds us that man's main objective is to avoid anxiety:

"I have tried to find one goal, which everyone would agree to be excellent and worthy of being striven after. I have found one only: to be free from anxiety"179.

All of Ibn Hazm's doctrinal positions that we have discussed conform to this goal of avoiding anxiety. Man must be anxious to gain salvation in the afterlife, but this anxiety will be more manageable the more the sphere of prohibition is minimized and the broader the categories of what is lawful or morally neutral and the greater the possibilities for forgiveness from God for transgressions. From this perspective, Zāhirism was an effective alternative to the tendency in Mâlikism - and other schools - to widen the categories of prohibition and cause believers who were not religious scholars to be more anxious about their fate. Such believers would be overwhelmed not only by their own lack of knowledge about the minutiae of what was right and wrong but also by the fact that decisions about right and wrong had been put in the hands of a group of "specialists".

In summary, Ibn Ḥazm's adoption of Z̄āhirism might have been motivated by his desire to salvage to whatever degree possible the features of the world in which he had been reared that were important to him. This world was threatened by Mālikī 'ulama' ', whose power had put Almanzor in a difficult position. Recall that he had been pressured by some Māliki fuqahā' to purge the caliphal library of al-Hakam II, and poets and men of letters had been persecuted and accused of faithlessness ${ }^{80}$, while enjoyable pastimes such as listening to music had come under moral reproach. There was a time when Ibn Hazm must have thought that he could help to recreate the world that had been lost by curbing the power of these fuqah $\bar{a}^{\prime}$. That was during the reign of Hishām III al-Mu'tadd, when Ibn Ḥazm and his Z̦āhirī teacher Abū I-Khiyār Mas'ūd b. Sulaymān b. Muflit (d. 426/1034) taught classes on Zāhirī doctrine in the great mosque of Córdoba, probably sometime between 418/1027 and 420/1029. At around the same time, in 421/1030, Ibn Ḥazm's friend, Ibn Shuhayd, was charged with publicly condemning the Mālikīs ${ }^{81}$. It hardly seems possible that these men could have acted without the support of the caliph, although he was under pressure from those who opposed the Zāhirīs. Hishām III was also facing

\footnotetext{
${ }^{78}$ Ibn Ḥazm, Kitāb al-akhlāq wa-l-siyar, Spanish translation by Miguel Asín Palacios, Los caracteres y la conducta, Madrid, Junta para Ampliación de Estudios e Investigaciones Científicas. Centro de Estudios Históricos, 1916; edition and French translation, N. Tomiche, Beirut, 1961; ed. E. Riad, Uppsala, 1980; English translation by Muhammad Abu Laylah, In Pursuit of Virtue: The Moral Theology and Psychology of Ibn Hazm Al-Andalusi (384-456 AH 994-1064 AD); with a Translation of His Book Al-Akhlaq Wa'l-Siyar, London: TaHa, 1990; edition and Spanish translation by Emilio Tornero, Madrid, 2007.

${ }^{79}$ Ibn Ḥazm, Kitāb al-akhlāq wa-l-siyar, translation in M. Abu Laylah, In Pursuit of Virtue..., p. 121-122; see also J. Puig, "Ibn H.azm y el estoicismo...", p. 85. Cf. Qur'an 5:6 and 22:78.

${ }^{80}$ Regarding these persecutions, see Maribel Fierro, La heterodoxia en al-Andalus durante el periodo omeya, Madrid, IHAC, 1987, p. 161-170.

${ }^{81}$ Teresa Garulo, La literatura árabe de al-Andalus durante el siglo XI, Madrid, Hiperión, 1998, p. 86.
} 
a critical scarcity of resources due to the civil unrest that had weakened Córdoba and the loss of control over most of Andalusi territory. With the help of his vizier, Hakam al-Qazzāz, he cast about for any means of raising money: confiscating the monies, jewels, and properties that Abū 'Āmir Ibn al-Muzaffar had left as a pious bequest ${ }^{82}$, and likewise the property of the son of a prominent Cordoban family, Ibn Dhakwān. In this desperate search for a source of revenue, Hishām III was able to count on the support of Abū I-Khiyār, described as "a rebel among those who sought to practice law" (mārid min al-mutafaqqihīn). This Abū l-Khiyār can be no other - as Bruna Soravia has pointed out - than Ibn Ḥazm's Z̦āhirī teacher. The policy of seizing property could only have alienated the good will of many who might have initially supported Hishām III. The Mālikī reacted by pressuring the caliph, who was at that time away from Córdoba at the frontier, and Ibn Ḥazm and his teacher Abū I-Khiyār wound up being expelled from the mosque for teaching Zāhirī doctrines ${ }^{83}$. Ibn Dhakwān, one of the injured parties in the confiscations, was a member of one of the prominent Cordoban families that would be decisive in the abolition of the caliphate. The fleeting Zāhirī interlude failed, but Ibn Ḥazm dedicated the rest of his life to putting down in writing a description of a society in which he and his allies would have been able to live without nostalgia for what had been lost, where they- and not the Māliki fuqaha $\bar{a}^{\prime}$ controlled the definition of what was right and wrong in Islamic terms while leaving ample room for the people to conduct their lives as usual ${ }^{84}$.

${ }^{82}$ Ibn Bassām, al-Dhakhīra fi maḥāsin ahl al-jazīra, ed. Iḥsān 'Abbās, Beirut, Dār al-Thaqāfa, 1975-1979, vol. I/1, p. 305; vol. III/1, p. 519.8 vols.

${ }^{83}$ Abū Ṭālib al-Marwānī (450H-516H), Kitāb 'uyūn al-imāma wa-nawāẓir al-siyāsa, ed. Bashshār 'Awwād Ma'rūf and Șalāḥ Muḥammad Jarrār, Tunis, Dār al-Gharb al-Islāmī, 1431/2010, p. 65-66. These pages correspond to the passage reproduced by M. Asín Palacios, Abenházam..., vol. I, p. 138-39, who cites an anonymous manuscript in the Khalduni Museum in Tunis, about which see Maribel Fierro, "Una fuente perdida sobre los ulemas de al-Andalus: el manuscrito del Museo Jalduní de Túnez", Al-Qanțara 12 (1991), p. 273-6.

${ }^{84}$ For how the son of another courtier - who had studied with Ibn Hazm - reacted to the new political situation created by the Almoravid intervention see Kenneth Garden, "From Courtier to Religious Scholar: The rihla and self-reinvention of Abū Bakr Ibn al-'Arab", Journal of the American Oriental Society 135-1 (2015), p. 1-18. 